\title{
Jurisprudent Analysis of Students' Cheating in Examination in China
}

\author{
Chen wei, Meng pei \\ Wuhan Institute of Physical Education Wuhan, Hubei, China \\ 18778720@qq.com; 54376105@qq.com
}

\begin{abstract}
Keywords: education examination; cheating; punishmen;, Examination Law
Abstract. Cheating in education examination is forbidden strictly by law, but it is still overwhelming in china. It influences school selecting excellent talents and keeping order. On the basis of collecting data and typical cases in education examination by statistics method, the author analyzes the relevant direct and indirect reasons. The occurrence of students' cheating in examination is closely related to the imperfection of law system and remedy system. In order to avoid disputes' recurrence, the government should enact Examination Law immediately and improve the management system of examination effectively.
\end{abstract}

\section{INTRODUCTION}

With the advancing of education reform and enhancing of students' legal awareness, disputes concerning education cheating have increased significantly. Examination, as an evaluation tool, is the embodiment of social justice and education justice. The increase of disputes in education examination reflects the problem in examination system to some extent. In order to protect justice and fair competition, we should improve the examination system. Among them, the safeguard of education law is fundamental.

\section{THE COMMON TYPES OF DISPUTES IN EDUCATION EXAMINATION}

In recent years, cheating in examination is prohibited in law, yet still rampant. There are so many different criminal conducts. Some students take usual cheating means to get high scores, like plagiarism; some staff in state agency indulges in malpractices; some social groups use modern tools to organize cheating. All these violating law should take legal consequence in light of the seriousness of the act. If litigants dissatisfied with the punishment, it may arouse disputes. In education examination, it includes the following types.

\section{A. Disputes arising from personal conduct}

A general exam cheating is conducted by individual. These are the traditional form of cheating. The examiners take the action just like using paper slips to cheat in exams, asking other people to take their own test, and passing answers in exam. These behaviors violate the examination rule but does not cause harm to society and also not constitute a violation of criminal acts. 1998, Decree of education administrative penalty enacted by the State Education Commission stipulates that deviance and punishment in cheating belongs to the area of administrative penalty.

In most cases, according to the rules or laws, individual who conducts cheating will be cancelled the examination qualification and given punishment by the school or testing agency. So disputes always occurred because individual didn't satisfy the punishment. Take one case for example; one college student who carried a radio receiver into the examination room was expelled from the school. The student assumed that school did not find out the facts so she filed a lawsuit against school.

\section{B. Disputes arising from collective behavior}

The nature of offenses conducted by collective behaviors is always serious. They violate the principle of fair competition. Most conducts have constituted a criminal offense. Some functionary of the State Administration agencies abuses his power, commits irregularities for the benefit of his relatives or friends, and falsifies results. Depending on the seriousness of the circumstances, they will be given administrative sanction, and their criminal responsibility shall be investigated according to law. Some other social groups charge high fees from examiners and transmit the exam 
answers to them by the means of modern communication. Take one case for example, in one school's entrance examination, an organized group of criminals use modern communication tools to transmit the exam answers to examiners to earn money. In the process of examination, teachers in the school stole the examination papers and sent them to the ringleaders, and the group hired people to floor the paper, and then send the answers to examiners who paid the high fees. The gangster earned more than twenty thousands in this examination.

The disputes on education examination not only include administrative disputes between schools and students but also include criminal disputes caused by serious test cheating. The executive and judicial branches should give the appropriate punishment according to the different cheating behaviors.

\section{THE ABSENCE OF LAW ABOUT THE EXAMINATION CHEATING}

Disputes occur and increase mainly because of the imperfection of law about the examination cheating. Relevant department can't enforce the law and punish the behaviors well because the existing law system does not cover all the areas and our country doesn't have a professional examination law to deal with all the examination problems.

A. The lack of a complete legal basis

Disputes should be judged according to the law, but now in our country, there are only regulations and documents enacted by Ministry of Education about examination cheating. So all the disputes are handled according to the existing regulations and documents, but several disputes can't find the proper rules as legal basis.

Education Law of the People's Republic of China made a basic general provision on the penalties for acts of cheating, "If anyone cheats in the national education exam, the education administrative department declares the score invalid." Consequently, State Council and Ministry of Education promulgated relevant administrative regulations including Provisional Regulations on self-study examination of higher education, Decree of education administrative penalty and Punishment Measures for Violations of Regulations in State Education Examinations and so on. Among them, Provisional Regulations on self-study examination of higher education published by the State Council in 1988 is by far our highest-level regulation of the education examination. Punishment Measures for Violations of Regulations in State Education Examinations published in 2004 becomes the main legal basis to give punishment. Meanwhile, the previous regulations about the examination punishment are repealed. But with the development of society, the legislation is seriously lagging behind the reality of society and it is unable to give complete legal basis.

In one case, public security organs have caught a gang who produces and sells cheating tools. But they can't find proper legal provisions about how to punish people who produces and sells cheating tools, so they can't give a proper punishment. Besides, according to the regulations, The Judiciary can only give the administrative punishments, but to serious cheating events, the existing law system in our country doesn't give a legal basis, so it causes difficulties for giving punishment.

\section{B. The lack of clear penalties}

In terms of the legal provisions about education examination, our country provides the principle of administrative penalties, but doesn't give more specific stipulation, so in the trials the free Jurisdiction Rights can't be regulated.

Because of the absence of clear penalties, schools and courts may give different ruling to the same case, which has caused some controversy. Take one cheating type as example, one university give a punishment of expulsion but another university gives a punishment of cancelling students' bachelor degree. In a case, Dong v. University, Dong asks the other student to take exam for him but found by teachers, so school give a punishment of cancelling students' bachelor degree. Students dissatisfied the school's punishment and bring a suit against the school. The court heard this case and ruled in favor of students. The judge said that the existing law doesn't give a clear provision that school can give students the punishment in the similar situation, so school can't give the punishment like this. 


\section{The lack of viable punishment procedures}

The administrative sanctions and penalties shall be decided by the organs in accordance with laws or administrative rules and regulations. When these organs make decisions on administrative penalty, they shall obey the specific forms, methods and steps that law regulates. In Law of the People's Republic of China on Administrative Penalty, article 31 regulates that before making a decision on administrative punishment, the executive authorities shall inform the parties of the facts the decision, reasons and legal basis. In Regulation of Student Management in Colleges, article 64 regulates that the punishment results should be informed to the parties, and the parties can defend, appeal and have their own dissenting opinions. Meanwhile schools should report the punishment to the provincial education department.

The existing laws have some provisions about punishment procedure, but there are still some problems and the procedure is too simple. At the same time by the influence of Chinese traditional ideas, legislation focuses only on penalties but neglects the protection of legitimate rights and setting punishment procedures. In general when invigilator found students cheating in the examination they would report directly to the school and then the school would give a punishment. In reality, most of the disputes about education examination are caused by the violation of legal procedure. In the case mentioned above, Lu V. University, the court ruled the student won the case. In the lawsuit, Lu said the school did not give the chance to defend before the punishment and not inform him after the punishment. In the light of this, the court ruled that the school violate the legal procedure so their punishment was invalid.

\section{The lack of perfect relief mechanism}

The relief mechanism is an important guarantee in order to protect the rights of candidates. Currently, the legislation of relief mechanism of examination system is not complete. In some situation, the interests of the candidates can't be guaranteed by timely and effective judicial relief, especially the disputes within schools.

Law of the People's Republic of China on Administrative Penalty regulates that if you disagree on the punishment decisions, you may apply for the reexamination, or you can bring a suit against the authority directly. However, it's not clearly regulated that which department can accept the application for review. Thus, the candidates cannot find the right department to bring a suit. Secondly, whether the disputes arising in schools can eventually be resolved by the court has not been established by the law. Education Law doesn't explicitly regulate either. Therefore, some courts do not accept students' disputes, and transferred to higher authorities to solve the problem, which substantially deprives the students of their legal rights.

\section{THE LEGAL MEANS TO AVOID DISPUTES IN EDUCATION EXAMINATION CHEATING}

As a right deriving from the education rights, examination right should be regulated in the jurisprudence. Only by strengthening the national examination administration building can we avoid disputes over the exam cheating effectively. The examination law not only standardizes the order of the national examinations, but also provides the effective legal protection and judicial relief for the majority of candidates to maintain the legitimate rights and interests.

\section{A. Provide legal protection to the examination right}

Examination right refers to the right to participate in the exam. The exam is held by the nation to assess the qualifications for a particular business or work after the evaluation of the qualification for the exam followed by citizens and residents' voluntary application. In nature, The examination is the scope and a follow-up part of the education right. As a law to protect rights and interests, examination law should include the exam rights and provides each candidate a fair and reasonable access to education resources through the standardization of the examination system.

Exam cheating seriously infringes upon the candidates' rights of fair competition. However, the existing legislation and punishment of cheating is mostly included in administrative penalties, which carries little legal weight. Therefore, it is necessary for the nation to legislate against cheating and promulgate the law to enhance the legal validity. The upcoming examination law is a special 
examination-related law, which will clearly define the discipline violation and law violation, provide a unified legal basis for punishing cheating and standardize exam discipline. Thus, the fair right of candidates to take part in exam will be protected.

Moreover, it is necessary that the procedure of penalties for cheating should be fair. The most important part of legislation is improving procedure of penalties for cheating. In order to protect the legitimacy of punishment procedures, the hearing procedures should be established and the candidates should be given the right to defense when the examination right of the candidates is involved.

\section{B. Attach importance to the judicial governance over punishment of cheating}

With the improvement of the legalization of penalty for cheating, great attention should be paid to the judicial governance. In the process of punishment to cheating, judicial agencies should be allowed to investigate the candidates and the staff when it is necessary in addition to the administrative punishment.

In the process of definition of legal responsibility to cheating, it should be scientifically classify the type of punishment to cheating and give a corresponding punishment including general educational treatment, administrative sanctions even criminal penalties according to the legal fact and the different degree of damage to others and the society. Although the Law of the People's Republic of China on Administrative Penalty issued in 2004 has severely punished those cheating in the exam, still most of its punishments are restricted to administrative penalties. In the formulation of the draft of examination law, some types of cheating have been defined as the violation of the law. The scope of punishment has been widened and the punishment has become more severe. Cheating, favoritism will be treated as offence even crime. The employed substitute and the employer may be fined, detained, or banned for test all life. Groups of malignant cheating will take legal responsibility even criminal responsibility. Large-scale, organized and premeditated leaking of examination papers for the sake of the private interests may be judged as crime of betraying state secrets. For the few cases leading to serious consequences, the prison term may be prolonged.

Secondly, it is necessary to draw a line between the rights of the court and the ministry of education, and explicitly defines each authority's duty. The lighter punishment such as demerits, warnings, etc should be resolved by the school administration, while the case involving severe punishment as expulsion or suspension from the school should be transferred to the court to make the final decree.

\section{Establish the perfect relief mechanism}

The judicial relief is entitled to social subject to resolve the conflict or disputes of the rights through certain ways and procedures to ensure they fulfill their legal obligation. Within the process, their stipulated right become a real right. In the dispute of exam cheating, when the plaintiffs think that their legitimate rights and interests are infringed, they may resort to relief mechanism. Therefore, the principal segment of the legislation is improving the judicial relief mechanism.

Legislation should expressly stipulate the way of judicial relief. If the abuse of power damaged examinee's legitimate rights and interests, they may seek judicial relief through administrative law. The examinee dissatisfied with the punishment decided by the administrative authority, can apply for administrative reconsideration to the superior administrative authority within fifteen days from receiving the decision of penalty. After receiving the appeal, the administrative authority must reply and announce the results within the stipulated time. At the same time, examinee can resort to judicial relief and bring an administrative suit before the people's court. However, in the process of improving the judicial relief mechanism, the legislation should be clearly defined the administrative organ receiving the appeal and administrative reconsideration to avoid sinking into the situation that the students have no access to appeal to safeguard their legal rights.

\section{CONCLUSION}

Our country is prepared to issue a new law Examination Law. Examination Law has higher validity. It will end the period in which administrative rules are used to deal with the disputes in 
exam. Thus, more complete legal system will protect the legitimate rights and interests of the examinee more effectively and reduce the corresponding litigation.

\section{REFERENCES}

[1] Li Xiaoyan. Education Law. Higher Education Press, 2001.

[2] Shi Xiang. On causes and solutions of disputes in university students' education. Journal of Higher Education Management, no. 1.

[3] Samuelson, Paul A. The Pure Theory of Public Expenditure. Review of Economics and Statistics, 1954, vol.36.

[4] Buchanan J·M. An Economic Theory of Clubs. Economic, 1965, vol.32.

[5] Marmolo, E.A Constitutional Theory of Public Goods. Journal of Economic Behavior \& Organization, 1999, vol.38.

[6] Goldin, Kenneth D. Equal Access VS Selective Access: A critique of Public Goods Theory. Public Choice, 1999, vol. 29.

[7] Wallace E.Oates. Fiscal Federalism, Harcourt Brace Jovanovich, Inc.35. 